\title{
The Natura 2000 network and the ranges of threatened species in Greece
}

\author{
Konstantina Spiliopoulou ${ }^{1,2}$ (D) . Panayiotis G. Dimitrakopoulos ${ }^{3}$ (D) \\ Thomas M. Brooks ${ }^{4}$ (D) - Gabriela Kelaidi ${ }^{2} \cdot$ Kaloust Paragamian $^{5}$ (D) Vassiliki Kati $^{6}$ (D) . \\ Anthi Oikonomou ${ }^{1}$ (D) . Dimitris Vavylis ${ }^{2} \cdot$ Panayiotis Trigas $^{7}$ (D) . Petros Lymberakis ${ }^{8}$ (D) \\ William Darwall $^{9}$ D $\cdot$ Maria Th. Stoumboudi ${ }^{1} \cdot$ Kostas A. Triantis $^{2}$ (D)
}

Received: 8 June 2020 / Revised: 13 January 2021 / Accepted: 20 January 2021 /

Published online: 13 February 2021

(c) The Author(s) 2021

\begin{abstract}
Global environmental goals mandate the expansion of the protected area network to halt biodiversity loss. The European Union's Natura 2000 network covers $27.3 \%$ of the terrestrial area of Greece, one of the highest percentages in Europe. However, the extent to which this network protects Europe's biodiversity, especially in a biodiverse country like Greece, is unknown. Here, we overlap the country's Natura 2000 network with the ranges of the 424 species assessed as threatened on the IUCN Red List and present in Greece. Natura 2000 overlaps on average $47.6 \%$ of the mapped range of threatened species; this overlap far exceeds that expected by random networks (21.4\%). Special Protection Areas and Special Areas of Conservation (non-exclusive subsets of Natura 2000 sites) overlap $33.4 \%$ and $38.1 \%$ respectively. Crete and Peloponnese are the two regions with the highest percentage of threatened species, with Natura 2000 sites overlapping on average $62.3 \%$ with the threatened species' ranges for the former, but only $30.6 \%$ for the latter. The Greek ranges of all 62 threatened species listed in Annexes 1 and II to the Birds and Habitats Directives are at least partially overlapped by the network $(52.0 \%)$, and $18.0 \%$ of these are fully overlapped. However, the ranges of 27 threatened species, all of which are endemic to Greece, are not overlapped at all. These results can inform national policies for the protection of biodiversity beyond current Natura 2000 sites.
\end{abstract}

Keywords Protected areas · IUCN red list · Threatened species · Greece · Natura 2000

Communicated by Stephen Garnett.

This article belongs to the Topical Collection: Biodiversity protection and reserves.

Konstantina Spiliopoulou

k.spilio@hcmr.gr

$\triangle$ Kostas A. Triantis

ktriantis@biol.uoa.gr

Extended author information available on the last page of the article 


\section{Introduction}

Biodiversity is severely threatened and declining in many parts of the world (Joppa et al. 2016b; Maxwell et al. 2016; IPBES 2019), raising concerns that an era of mass extinction is beginning (Dirzo et al. 2014; Lewis and Maslin 2015). According to the IUCN Red List of Threatened Species, more than $27 \%$ of the 105,700 species assessed, face "a high risk of extinction in the wild" (IUCN 2019). Over recent years, in response to this increasing biodiversity loss, great effort has been allocated in implementing strategies for the protection of nature. Protected areas have long been regarded as one of the most valuable tools for the protection of biodiversity (Chape et al. 2008; Watson et al. 2014), and so play a major role in these strategies. The 2011-2020 Strategic Plan for Biodiversity's Aichi Target 11 states that, by 2020 , at least $17 \%$ of terrestrial and inland water areas and $10 \%$ of coastal and marine areas, should be effectively managed by protected areas and "other effective areabased conservation measures" (OECMs; CBD 2010). According to the Protected Planet live-report (www.protectedplanet.net), $15 \%$ of terrestrial and freshwater environments and $7.8 \%$ of the marine environment are protected (UNEP-WCMC \& IUCN 2020). In addition to Aichi Target 11, the Sustainable Development Goals (SDGs) 14 and 15 call for protection of the planet's marine, terrestrial and freshwater biota (United Nations 2015). These global targets and goals, as well as the post-2020 agenda (CBD 2020), advocate expansion of the protected area network at the regional and national level in order to halt biodiversity loss.

Although protected areas are considered a critical tool to conserve biodiversity, there is still no comprehensive answer to whether they actually deliver on this commitment. While some analyses have revealed impacts of protected areas in reducing rates of habitat loss (Andam et al. 2008; Joppa and Pfaff 2011; Geldmann et al. 2013) and reducing increases in extinction risk for species (Butchart et al. 2012), for most taxa the conservation outcomes of protected areas are unknown (Joppa et al. 2016a). Generally, the greater the overlap of a species distribution by protected areas, the higher the chances for long term persistence ought to be (e.g. Rodrigues et al. 2004a, b); but the overall conservation outcome is highly dependent on the specific environmental context (e.g. hydrology), as well as the particular protected area planning, management scheme, governance and budget allocation (Rodrigues et al. 2004a, b; Watson et al. 2014).

The European Union has the largest coordinated network of protected areas in the world (European Commission 2020). The Natura 2000 is a network of protected areas that was established in 1992, operating under the European Union's Birds and Habitat Directives. It is comprised of two non-mutually exclusive site types, Special Protection Areas (SPAs) and Special Areas of Conservation (SACs) (European Commission 1992, 2009). By 2019, one year before the end of the Strategic Plan for Biodiversity 2011-2020, Natura 2000 sites had covered $18 \%$ of the terrestrial, and almost $9.5 \%$ of the marine, European Union territory. Terrestrial coverage of the Natura 2000 varies among the European Union countries between $8.4 \%$ and $37.8 \%$ (European Environment Agency 2019).

While the Natura 2000 network aims to "ensure the long term survival of the most valuable and threatened species and habitats in Europe" (European Commission 2020), biodiversity is not evenly distributed throughout Europe. The southern European countries, which belong to the Mediterranean biodiversity hotspot, are characterized by higher levels of threat to biodiversity and have higher levels of endemism than the rest of Europe (Médail \& Quézel 1999; Myers et al. 2000). Greece is exceptionally diverse. Despite its relatively small size $\left(131,940 \mathrm{~km}^{2} ; 1.3 \%\right.$ of Europe and $3 \%$ of the European Union's area), 
it contributes significantly to the European biodiversity with almost $32 \%$ of the known European species being present in Greece (Aravanopoulos 2010). Due to its high topographic heterogeneity, complex paleogeographic history, fragmented landscape, and location at the crossroad of three continents, i.e. Europe, Asia and Africa, Greece hosts a very high number of species and has high levels of endemism (Legakis and Maragkou 2009; Sfenthourakis et al. 2018; Legakis et al. 2018). It is estimated that Greece has about 50,000 animal species, more than $20 \%$ being endemic (e.g. Legakis et al. 2018) and more than 5800 vascular plant species, more than $22 \%$ endemic (Flora of Greece Web 2018). The degree of endemism for some taxonomic groups, especially those that have diversified in insular systems, exceeds 50\% (e.g. Sfenthourakis et al. 2018). However, Greece also has the second highest number of threatened species in Europe as well as in the Mediterranean biodiversity hotspot, after Spain (BirdLife International 2017; IUCN 2019).

In Greece, the Natura 2000 network covers $27.3 \%$ of the terrestrial area. This is one of the highest levels of protected area coverage in Europe, and is far above the $17 \%$ coverage mandated by Aichi Target 11. However, it remains unclear how well this represents the threatened biodiversity of Greece. Two studies have evaluated representation of species by protected areas in Greece. One, focused on 1624 native plant species in Crete, found that SAC sites do not represent satisfactorily the regional plant biodiversity (Dimitrakopoulos et al. 2004). The other, on 395 vascular plant species and subspecies endemic to Peloponnese found low overlap with selected networks from complementarity analysis (Trigas et al. 2012). Here, we assess the overlap between the 424 extant, native, resident species assessed as threatened on the IUCN Red List and present in Greece, and the country's Natura 2000 network. We then compared our results against null models obtained by placing equivalent "Natura 2000" sites at random over the land area of Greece.

\section{Materials and methods}

\section{Natura 2000}

Of 1288 (overlapping) protected areas in Greece (UNEP-WCMC 2020), 446 sites are part of the Natura 2000 network, including 239 Special Areas of Conservation, 181 Special Protection Areas, and 26 sites that are both (Fig. 1). Special Areas of Conservation are designated to ensure the favorable conservation status of each habitat type and species listed in the Annexes of the Habitats Directive (European Commission 1992), while Special Protection Areas are designated for 194 particularly threatened species and all migratory bird species listed in the Annexes of the Birds Directive (European Commission 2009). These sites together cover $36,000 \mathrm{~km}^{2}(27.3 \%)$ of the country's land territory; SACs cover $16.6 \%$ and SPAs cover $20.9 \%$ with overlaps between the two site types of $10.2 \%$. Geographical Information System (GIS) data on Natura 2000 sites were downloaded from the European Environmental Agency (2019).

\section{Threatened species}

We considered all species with known presence in Greece, according to the IUCN Red List (IUCN 2019). As of March 2019 there were 3280 species assessed for Greece, of which 2809 are terrestrial and freshwater species. Of all species assessed, animals represent $73.1 \%$ (2055 species; 4\% of the entire Greek fauna) and plants represent $26.8 \%$ 


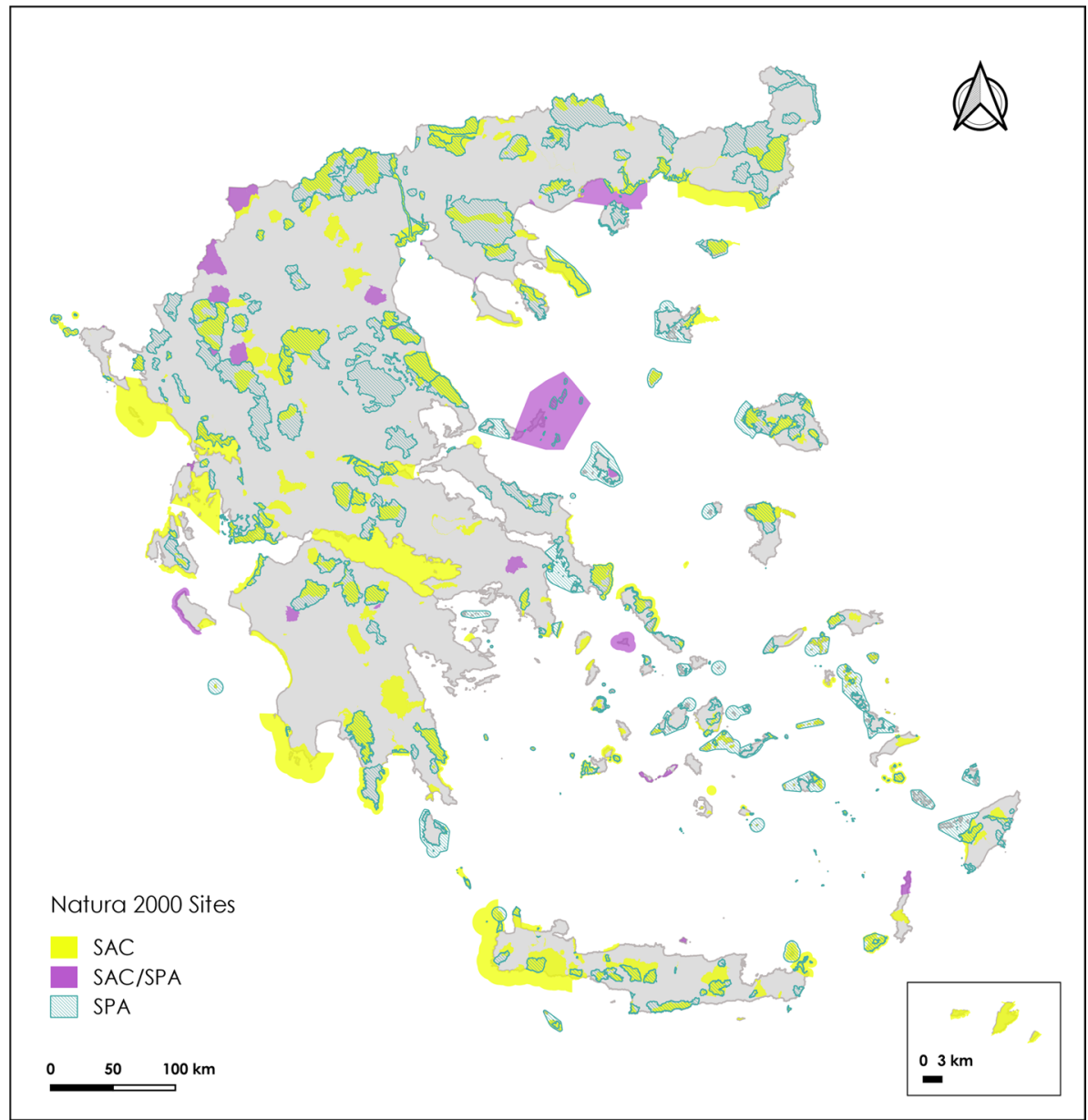

Fig. 1 The Natura 2000 network in Greece. Yellow represents Special Areas of Conservation (SACs), light blue stripes represent Special Protection Areas (SPAs) and purple represents sites that are designated as both SAC and SPA

(753 species; 13\% of the entire Greek flora). For some taxonomic groups (e.g., tetrapod vertebrates, freshwater fishes, land snails), almost all Greek species has been assessed for the IUCN Red List; for others (including most invertebrate and plant groups), assessments are not comprehensive, and may be biased (e.g., towards species a priori considered likely to be threatened, or towards particular regions). Throughout, we used the global extinction risk status for each species, not the national one (e.g., Phitos et al. 1995; Legakis and Maragkou 2009), consistent with our objective to evaluate the contribution of the Natura 2000 network of Greece to the protection of the global biodiversity, and thus the progress of the country towards global environmental targets.

The threatened species, i.e. those assigned to Vulnerable (VU), Endangered (EN) and Critically Endangered (CR) categories, total 476 species (Table 1). We followed the taxonomy used by the IUCN Red List, but we grouped the plant classes of Liliopsida and Magnoliopsida into Magnoliopsida (following Euro+Med 2006). Four Greek species, all gastropods, 
Table 1 Numbers of terrestrial and freshwater species in each Class assessed on the IUCN Red List, in each threat category, and the percentage (\%) of threatened species

\begin{tabular}{lcllllr}
\hline Class/group & $\begin{array}{l}\text { Number of } \\
\text { assessed species }^{\mathrm{a}}{ }^{\mathrm{n}}\end{array}$ & $\begin{array}{l}\text { Number of threat- } \\
\text { ened species }\end{array}$ & VU & EN & CR & $\begin{array}{r}\text { \% of threat- } \\
\text { ened species }\end{array}$ \\
\hline Gastropoda & 647 & 173 & 113 & 24 & 36 & 26.7 \\
Insecta & 423 & 124 & 66 & 45 & 13 & 29.3 \\
Actinopterygii & 123 & 45 & 13 & 15 & 17 & 36.6 \\
Magnoliopsida & 633 & 69 & 29 & 25 & 15 & 10.9 \\
Aves & 435 & 25 & 17 & 4 & 4 & 5.7 \\
Reptilia & 58 & 11 & 8 & 3 & 0 & 19.0 \\
Mammalia & 99 & 9 & 7 & 2 & 0 & 9.1 \\
Amphibia & 23 & 5 & 3 & 1 & 1 & 21.7 \\
Bivalvia & 19 & 5 & 2 & 3 & 0 & 26.3 \\
Polypodiopsida & 15 & 3 & 2 & 1 & 0 & 20.0 \\
Malacostraca & 8 & 3 & 3 & 0 & 0 & 37.5 \\
Lycopodiopsida & 4 & 2 & 0 & 1 & 1 & 50.0 \\
Cephalaspidomorphi & 1 & 1 & 0 & 0 & 1 & 100.0 \\
Agaricomycetes & 1 & 1 & 1 & 0 & 0 & 100.0 \\
Pinopsida & 17 & 0 & - & - & - & 0.0 \\
Total & 2506 & 476 & 264 & 124 & 88 & 19.0 \\
\hline
\end{tabular}

Classes/groups with the majority ( $>90 \%$ ) of their species assessed are highlighted in bold.

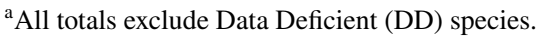

assessed as Extinct, Zonites santoriniensis, Zonites siphnicus, Vitrea storchi and Graecoanatolica macedonica, were excluded from the analyses.

Among species groups comprehensively assessed, Actinopterygii, Gastropoda, and Amphibia have the highest threat prevalence of threatened species: $36.6 \%, 26.7 \%$, and $21.7 \%$ respectively (Table 1).

For all threatened species, we downloaded the available range maps from the IUCN Red List website (www.iucnredlist.org). Range maps represent the 'current known limits of distribution of a species, accounting for all known, inferred or projected sites of occurrence' (IUCN 2016). We only considered species that have extant, resident and native distributions which account for code 1 in Presence (extant), Origin (native) and Seasonality (resident) following the IUCN Red List mapping standards (IUCN 2018), yielding 424 extant, native, resident threatened species with mapped Greek ranges. Of these, 323 are terrestrial, 97 are freshwater species and four are amphibious species. Out of the 424 threatened species, 303 (71.5\%) are endemic to Greece. According to Annexes 1 and II of the Birds and Habitats Directives, 62 of the 424 threatened species in this study are formally protected by the Natura 2000 network.

For Aves, since we included only species with permanent presence in the country, we excluded from the analysis the migrating species (summer, winter and passage visitors) and vagrants. 


\section{Measuring the actual and expected overlap of threatened species ranges with the Natura 2000 network}

Following existing approaches (Rodrigues et al. 2004b; Araújo et al. 2007; Watson et al. 2010; Beresford et al. 2011; Cantú-Salazar et al. 2013; Trochet and Schmeller 2013; Venter et al. 2014; Abellán and Sánchez-Fernández 2015; Klein et al. 2015; Shanee et al. 2017), we overlapped the Natura 2000 network with the species range maps, and we calculated the percentage of overlap using the formula:

$$
\frac{\text { area }_{\text {natura }}}{\text { area }_{\text {range }}} \times 100
$$

where area $_{\text {natura }}$ is the size of the species range that overlaps with the Natura 2000 network in Greece, and area $_{\text {range }}$ is the size of the species range in Greece.

We calculated the overlap of the Greek ranges of threatened species by the whole of the Natura 2000 network and the individual site types, SACs and SPAs separately. This is because SPA and SAC sites have been designated to protect different taxa (SPAs solely for the protection of bird species, while SAC sites for the rest of the species). For calculating the overlap by the individual Natura 2000 site types, we used the sites designated as SAC/ SPA in the calculations for the overlap both with SACs and SPAs. For the overlap with the whole of the Natura 2000 network we considered all overlapping areas of the sites as a single area value. The above analysis was repeated only for the classes/groups comprehensively assessed (see Table 1), in order to test for potential biases due to the fact that some classes have a low percentage of species assessed in the IUCN Red List.

We evaluated the overlap against random, simulated protected area systems (e.g. Guilhaumon et al. 2015; Rosso et al. 2018) in order to explore whether the overlap of the Natura 2000 network in Greece with the ranges of threatened species differs from that expected by chance. We used a null model to generate 999 random networks of protected areas across Greece, with the same land coverage and configuration (i.e. shape) of existing Natura 2000 sites. The algorithm used, randomly changes the centroid - therefore the location-and rotates each Natura 2000 site on the terrestrial part of Greece. The model is constrained to ensure that each site has a location that does not overlap with marine areas, nor with other Natura 2000 sites and big cities, and that the total land coverage of the random networks is the same to the current Natura 2000 network (see Guilhaumon et al. 2015; Rosso et al. 2018). Probability values were estimated as the proportion of mean overlap values from random systems that are equal or greater than the observed overlap value (P hereafter, with $\mathrm{P}=\mathrm{P}$ (Random $\geq$ Observed)), by inspecting the positions of the observed value in the corresponding null distributions.

The analysis was conducted using the R programming language version 3.6.1 (https:// www.r-project.org/) and the "sf" $\mathrm{R}$ package. The code for the analysis is available at https ://zenodo.org/deposit/4436399.

\section{Results}

The mean percentage overlap between the ranges of threatened species in Greece and the Natura 2000 network is $47.6 \%$ (recall that Natura 2000 sites cover $27.3 \%$ of Greece's land area; for the respective median values see Table S1). The individual site types that 
comprise Natura 2000, SPAs and SACs, overlap the ranges of threatened species by $33.4 \%$ and $38.2 \%$ respectively (compared to $20.9 \%$ and $16.6 \%$ coverage of land area, respectively; Table 2). For the percentage overlap for each individual species' Greek range by the Natura 2000 network see supplementary materials (Table S2).

Among the most comprehensively assessed classes/groups (Table 1), Actinopterygii (51.3\%), Gastropoda (48.8\%) and Reptilia (46.1\%) have the highest overlap with the Natura 2000 network. Our focus on resident species may explain the relatively low overlap for Aves (29.3\%), given that 13 threatened bird species occur in Greece only as winter visitors, migrants, or vagrants.

Among the 62 threatened species listed in the Annexes of the Birds and Habitats Directives, all have at least part of their range within the Natura 2000 network in Greece. The majority of these species (51) are partially overlapped and 11 of them (18\%) are fully overlapped (>99\%). The mean overlap for the 62 Annexed species is $52.0 \%$.

Twenty-seven $(6.4 \%)$ out of the 424 species in this analysis had no overlap with the Natura 2000 network (overlap $<0.1 \%$ ), while $46(10.8 \%)$ species had less than $10 \%$ overlap. All of these species belong to the class Gastropoda, except for two Magnoliopsida and nine Insecta. Almost half (19) of the species with $<10 \%$ overlap are present in Peloponnese (12 species) and Crete ( 7 species). There are no threatened species with $<10 \%$ overlap present in Western Macedonia, Central Macedonia and Eastern Macedonia and Thrace, while species with $0 \%$ overlap are present in the islands, Epirus, Central Greece, Attica and Peloponnese (Fig. 2). We estimate that $4.8 \%$ increase of the Natura 2000 network will result in covering at least $10 \%$ of the ranges of all threatened species in Greece.

The mean overlap of species ranges among the threatened categories is $51.2 \% \pm 4.1$ (mean \pm Standard Error) for Critically Endangered species, $46.5 \% \pm 2.8$ for Endangered species, and $47.1 \% \pm 2.3$ for Vulnerable species. We found no significant difference on the overlap among the three threat categories (one-way ANOVA, p-value $=0.59$ ). Similarly, we found no significant difference between the terrestrial and freshwater species (t-test, p-value $=0.67$ ), using data on habitat and ecology for each species from the IUCN Red List to divide into "terrestrial" $(n=327$ species $)$ and "freshwater" $(n=101$ species $)$ systems (four species are coded as both). The overlap of their ranges with the Natura 2000 network, but also the SPAs and SACs, is generally similar, although SPAs overlap the ranges of threatened freshwater species to a greater extent than they do for terrestrial species (Table 3). Analyses using only the comprehensively assessed classes/groups yield very similar results (Tables S3-S5; Figs. S1, S2).

The percentage of overlap with the Natura 2000 for the ranges of threatened species in Greece is higher than offered by random networks $(\mathrm{P}=1$; Fig. 3$)$. This is also the case for all classes individually, except from Malacostraca (the largest crustacean Class, for which only two threatened species have been documented in Greece), for which the overlap by the Natura 2000 is lower than expected considering random networks $(\mathrm{P}=0.969$; Fig. S3). One-hundred and twelve species $(26.4 \%)$ are expected by random networks to have $<0.1 \%$ overlap with the Natura 2000 network (compared to 27 or $6.4 \%$ observed).

The percentage of overlap with the Natura 2000 network for each one of the threat categories (Vulnerable, Endangered and Critically Endangered) is also higher to that offered by random networks $(\mathrm{P}=1)$. For terrestrial and freshwater species, the percentage of overlap with the Natura 2000 is again higher than that offered by random networks $(\mathrm{P}=1)$.

The 62 threatened species listed in Annexes 1 and II to the Birds and Habitats Directives are expected by random networks to have $22.9 \%$ (compared to $52.0 \%$ observed) overlap with the Natura 2000 network. No annexed species (compared to 11 species or 18\% observed) is expected by random networks to have $100 \%$ overlap with the network. 


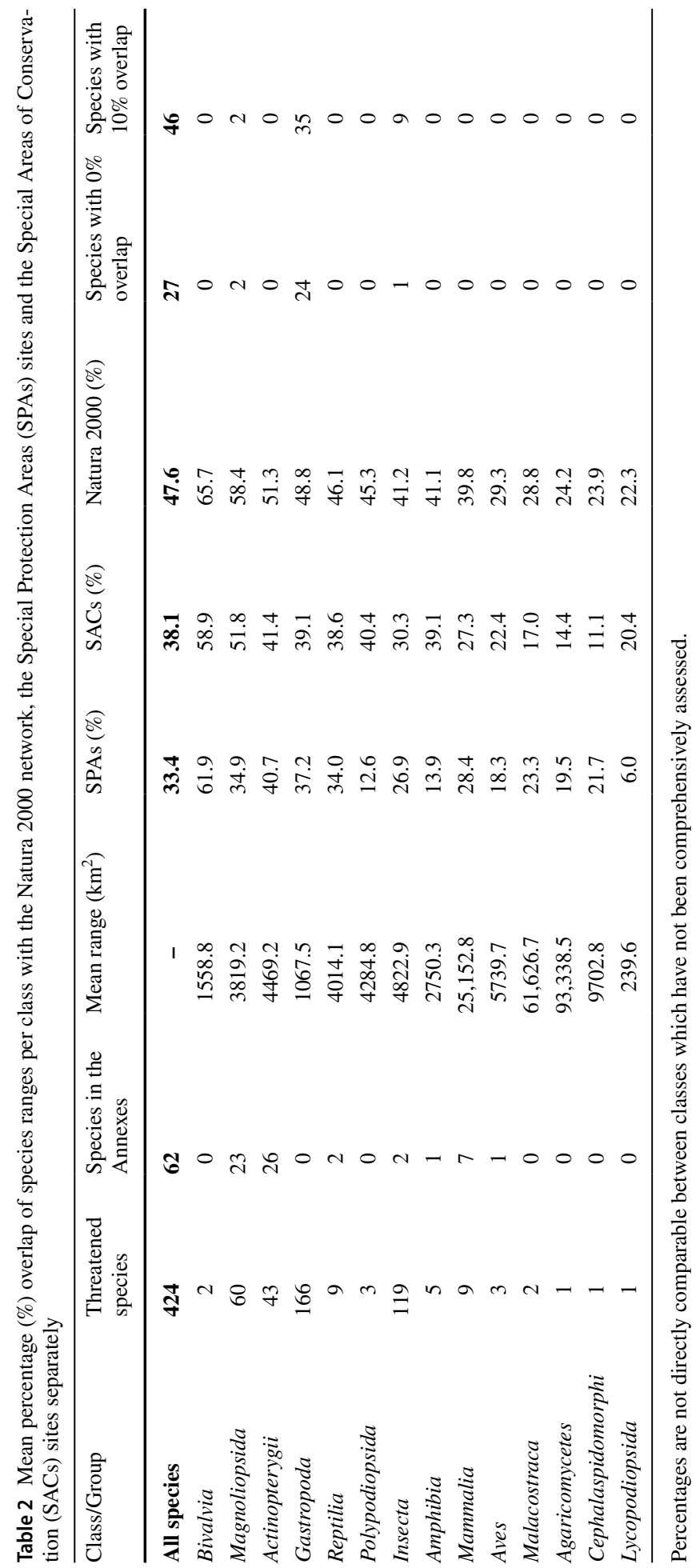




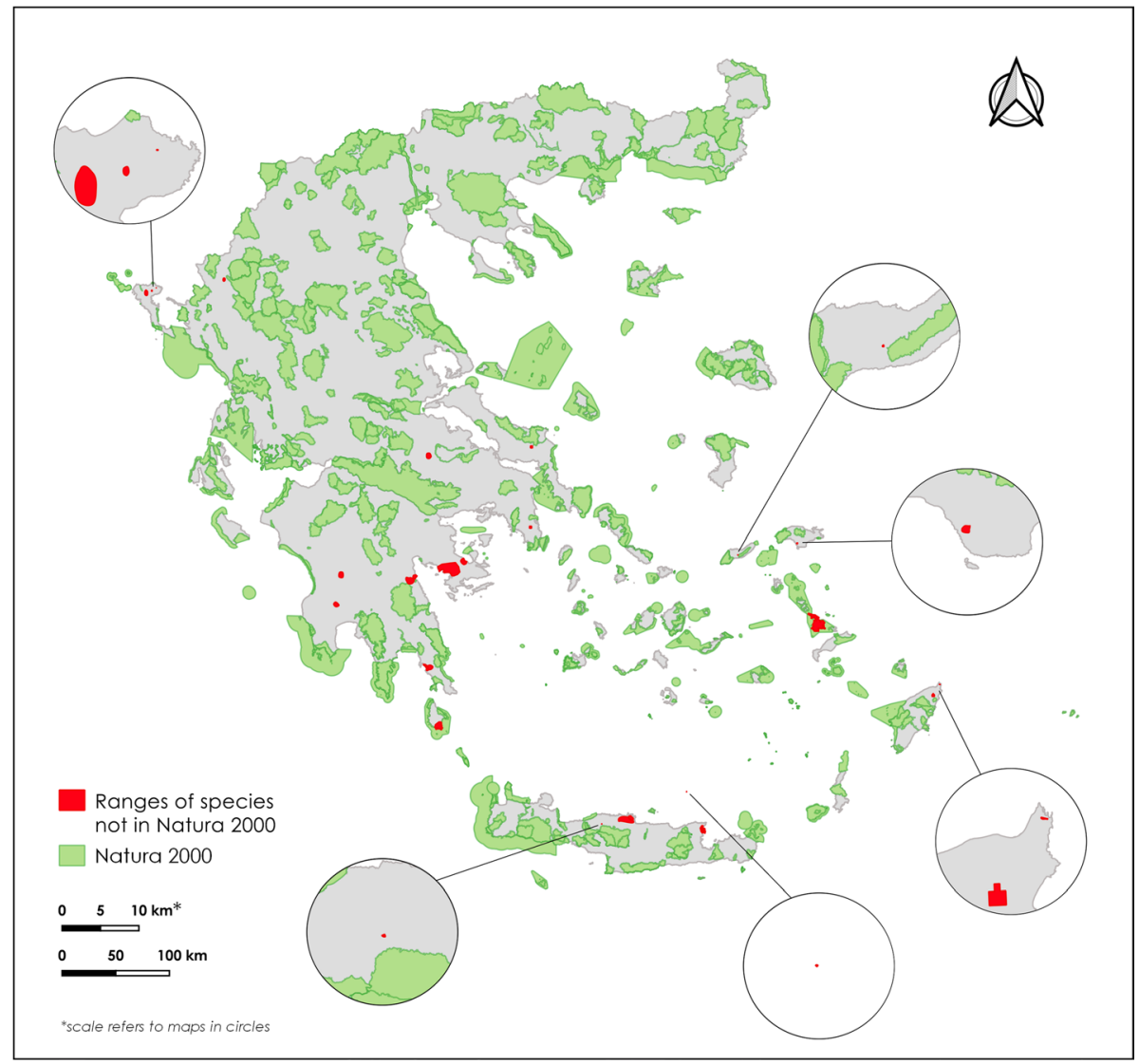

Fig. 2 The location of threatened species ranges (Red) that have no overlap with the Natura 2000 network and the Natura 2000 sites (Green) in Greece

Table 3 Mean percentage (\%) overlap of threatened species ranges with the Natura 2000 network, SPAs and SACs for terrestrial and freshwater species

\begin{tabular}{llll}
\hline System & Natura 2000 (\%) & SPAs $(\%)$ & SACs $(\%)$ \\
\hline Terrestrial & 47.7 & 31.6 & 38.3 \\
Freshwater & 46.0 & 38.3 & 36.4 \\
\hline
\end{tabular}

The percentage of threatened species in Greece across the 13 administrative regions increases southwards. Crete and Peloponnese are the two regions with the highest percentage of threatened species ( $12.0 \%$ and $9.7 \%$ respectively). To the north, although species richness increases, the percentage of threatened species per region decreases (Fig. 4; Table S6). Eastern Macedonia and Thrace (5.5\%) and North Aegean (4.9\%) are the two regions with the lowest percentage of threatened species. The mean overlap per 


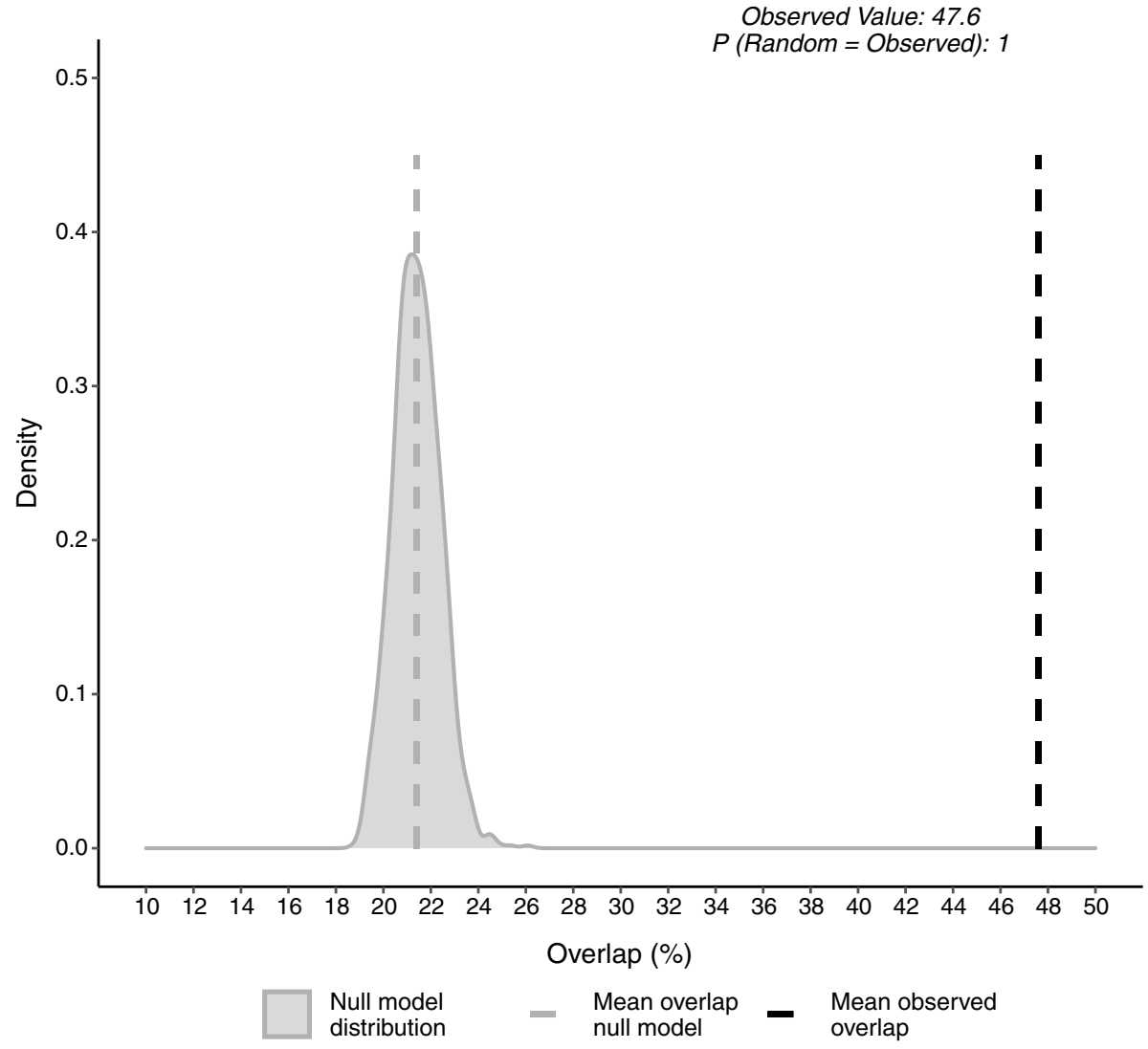

Fig. 3 The distribution of the percentages of overlap between the Greek ranges of threatened species (424) and the 999 random networks obtained by the null model (light grey), the mean percentage overlap obtained by the null model (grey dashed line) and the mean percentage overlap observed between the Greek ranges of threatened species (424) and the current Natura 2000 network in Greece (black dashed line)

Class with the Natura 2000 in each administrative region can be found at the supplementary materials (Table S7).

Regions contribute at different levels to the total overlap for threatened species ranges in Greece (Fig. 4). Crete provides the highest mean overlap of threatened species' ranges (62.3\%), followed by South Aegean (54.3\%). The regions with the lowest percentages are Western Greece (29.4\%) and Attica (18.6\%).

\section{Discussion}

Protected areas are a critical tool for the protection of nature. However, the effectiveness of protected areas still remains a highly debated topic (Watson et al. 2014; Joppa et al. 2016a; Acreman et al. 2019). Several indices have been used to evaluate protected areas, e.g. governance, budget allocation and management plans. Although these parameters provide an indirect evaluation of protected area performance, some correlation with favorable 


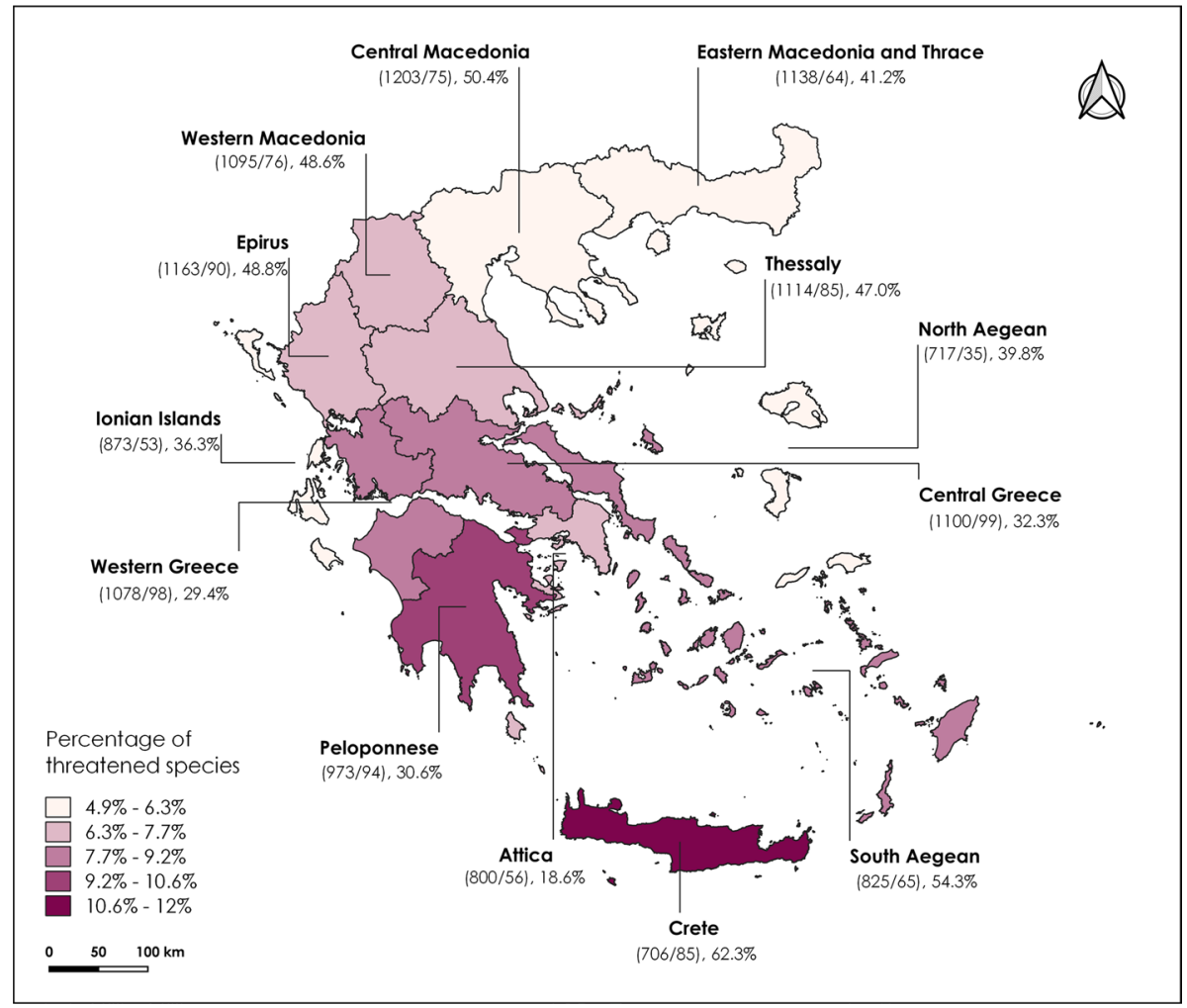

Fig. 4 Percentage (\%) of threatened species per administrative region in Greece. Darker hue of purple represents higher percentage of threatened species. Numbers under the names of the regions represent the total number of species (first number in brackets; derived from IUCN Red List range maps), the total number of threatened species (second number in brackets; again derived from IUCN Red List range maps) and the mean percentage (\%) overlap of threatened species' ranges with the Natura 2000 per region (Table S7)

conservation outcomes has been shown (Bruner et al. 2001; Leverington et al. 2010; Geldmann et al. 2018; Coad et al. 2019). Other approaches use representation targets for individual species, based on the area they occupy and on the percentage of the global distribution range occurring in the focal regions (Rodrigues et al. 2004a; Maiorano et al. 2015), or calculate an index of representation for Annex II species of the Habitats Directive in the Natura 2000 network (Gruber et al. 2012).

The percentage of overlap of species ranges is another metric used to evaluate protected areas. In comparison to other metrics, this uses distribution data for multiple species. The percentage of overlap of species ranges with protected areas has been used in studies at the global scale (e.g. Rodrigues et al. 2004a, b; Cantú-Salazar et al. 2013; Venter et al. 2014), regional scale (e.g. Watson et al. 2010; Trochet and Schmeller 2013; Abellán and SánchezFernández 2015) and national scale (Araújo et al. 2007; Shanee et al. 2017). However, these studies mainly focused on the better known chordate taxa (birds, mammals, reptiles and amphibians).

Our study evaluates the whole of the Natura 2000 network in Greece-which provides a better coverage than provided by random networks (Fig. 3) - using all threatened species data available, for 424 species encompassing both vertebrate and invertebrate, 
as well as plant, taxa; thus we have not focused solely on the species listed in the Annexes of the Habitats and Birds Directives, but all threatened species and not to specific regions but the whole country. No difference on the overlap between terrestrial and freshwater species was observed. A similar study at the European scale, using data from 300 species overall, with the most being fish, showed $35 \%$ overlap between the ranges of 76 threatened species and the Natura 2000 network in Greece (Trochet and Schmeller 2013). Our results show a higher degree of overlap of species ranges with the Natura 2000 network probably due to many more IUCN Red List assessments being conducted since 2013, and due to the Natura 2000 network in Greece being expanded in 2017.

Our finding that the SPA and SAC sites separately overlap the ranges of threatened species in Greece at $33.4 \%$ and $38.2 \%$ respectively, is consistent with expectations based on the fact that these two categories have been established based on different criteria and with different aims. Specifically, SACs should have a higher overlap of threatened species ranges compared to SPAs, which are designed for the protection of birds only. The fact that there is no significant difference in the overlap among the three threat categories (CR, EN and VU) with the Natura 2000 network (one-way ANOVA, p-value $=0.59$ ) is also interesting. Re-analyzing the percentages of overlap for each species using the data provided by Trochet and Schmeller (2013; Appendix 1), the pattern remains the same (one-way ANOVA, p-value=0.33). The overlap of all threatened species ranges with the Natura 2000 network - regardless of the level of threat they face-is important to the conservation of threatened biodiversity. That said, the expansion of the network, in order to increase the overlap with the ranges of species facing imminent extinction, could be considered as a policy response. Additionally, as we saw an increase of $4.8 \%$ would result to the coverage of at least $10 \%$ of all the threatened species.

Greece has higher species richness in the northern part of the country and higher endemism in the south. Endemic species are more sensitive to changes (e.g. Gaston 1994) which could explain the higher number of threatened species in southern administrative regions (e.g. Crete and Peloponnese). Although the overlap between threatened species and the Natura 2000 network in Crete is quite high (62.3\%), that in Peloponnese is only $30.6 \%$ (the third lowest in Greece), highlighting the need to expand and potentially re-structure the conservation network in this part of the country. Western Greece and Attica regions provide the lowest overlap between threatened species and Natura 2000. Increasing the conservation efforts in these regions, and also in regions that have high percentages of threatened species but relatively low overlap with the Natura 2000 network (e.g. Peloponnese) will contribute substantially to the protection of threatened biodiversity in Greece. Such efforts could be achieved through multiple pathways: for example, through expansion of the Natura 2000 network, as was achieved in 2017 (Joint Ministerial Decision 50743/2017), or by implementation of complementary conservation approaches such as community protected areas (Dudley 2008), or "other effective area-based conservation measures" (IUCN WCPA 2019), or by restoration (Carrizo et al. 2017).

For Greece, the protection of threatened species-the majority of which are endemics (71.5\%) — offers significant contribution to the global biodiversity. The results presented herein can inform national policies for the protection of biodiversity. Five aspects can be identified: (a) determine the threatened species that have zero or low overlap with the Natura 2000 network in Greece; (b) increase the levels of protection for the species with the most imminent threat of extinction; (c) restore critical ecosystems; (d) pinpoint the regions that are of critical importance for the biodiversity of Greece, as they contain the highest 
percentages of threatened species; (e) highlight the regions with low mean Natura 2000 overlap with their threatened species ranges.

In order to accomplish more efficient protected area networks, several prioritization and planning tools are available. One such tool is Key Biodiversity Areas (KBAs), which implements the long-standing concept of important areas for the persistence of biodiversity, across all taxonomic groups. The Standard for the Identification of KBAs was recently released (IUCN 2016) and it could be used to identify sites that will strengthen the protected area network in Greece, possibly also through harnessing "other effective area-based conservation measures" as a complement to the Natura 2000 network. KBAs themselves can also provide benefits to threatened species-even if they are not within protected areas-as they can stimulate environmental safeguards.

\section{Conclusion}

Greece has met the percentage coverage of area specified by Aichi target 11 and has one of the most extensive Natura 2000 networks in the European Union. Moreover, the current network is demonstrably superior to a random placement of the sites. However, it fails to adequately represent all threatened species that are of priority for protection globally, with 27 endemic species wholly unrepresented. Expansion of the network to encompass populations of these species would put Greece at the forefront of countries fulfilling their EU's Biodiversity Strategy for 2030, and their responsibility to safeguard global biodiversity, which would be a remarkable result given its concentration of endemic and threatened biodiversity. Results herein should be complemented with other available approaches such as habitat restoration and approaches that evaluate protected areas such as governance, institutional framework and stability, budget allocation, management plans and gap analysis for species listed in the annexes of the Habitats and Birds Directives, in the case of Europe.

Supplementary Information The online version contains supplementary material available at https://doi. org/10.1007/s10531-021-02125-7.

Acknowledgements We would like to thank Francois Guilhaumon and Stephen Garnett for their valuable contribution to this paper. This project has received funding from the European Union's Horizon 2020 research and innovation programme under the Marie Skłodowska-Curie Grant Agreement No. 766417. This communication reflects only the authors' view and the Research Executive Agency of the European Union is not responsible for any use that may be made of the information it contains

Funding This project has received funding from the European Union's Horizon 2020 research and innovation programme under the Marie Skłodowska-Curie Grant Agreement No. 766417.

Data availability The datasets analysed during the current study are available in the European Environmental Agency, https://www.eea.europa.eu/data-and-maps/data/natura-11 and the IUCN Red List of Threatened Species, https://www.iucnredlist.org/search.

Code availability The code developed for the purpose of this study is available at https:// zenodo.org/deposit/4436399. 


\section{Compliance with ethical standards}

Conflict of interests The authors have no conflicts of interest to declare.

Open Access This article is licensed under a Creative Commons Attribution 4.0 International License, which permits use, sharing, adaptation, distribution and reproduction in any medium or format, as long as you give appropriate credit to the original author(s) and the source, provide a link to the Creative Commons licence, and indicate if changes were made. The images or other third party material in this article are included in the article's Creative Commons licence, unless indicated otherwise in a credit line to the material. If material is not included in the article's Creative Commons licence and your intended use is not permitted by statutory regulation or exceeds the permitted use, you will need to obtain permission directly from the copyright holder. To view a copy of this licence, visit http://creativecommons.org/licenses/by/4.0/.

\section{References}

Abellán P, Sánchez-Fernández D (2015) A gap analysis comparing the effectiveness of Natura 2000 and national protected area networks in representing European amphibians and reptiles. Biodivers Conserv 24:1377-1390. https://doi.org/10.1007/s10531-015-0862-3

Acreman M, Hughes KA, Arthington AH, Tickner D, Dueñas M-A (2019) Protected areas and freshwater biodiversity: A novel systematic review distils eight lessons for effective conservation. Conserv Lett 13:e12684. https://doi.org/10.1111/conl.12684

Andam KS, Ferraro PJ, Pfaff A, Sanchez-Azofeifa GA, Robalino JA (2008) Measuring the effectiveness of protected area networks in reducing deforestation. Proc Natl Acad Sci USA 105:16089-16094. https:// doi.org/10.1073/pnas.0800437105

Araújo MB, Lobo JM, Moreno JC (2007) The effectiveness of Iberian protected areas in conserving terrestrial biodiversity. Conserv Biol 21:1423-1432. https://doi.org/10.1111/j.1523-1739.2007.00827.x

Aravanopoulos FA (2010) The importance of the biodiversity of Hellenic forest and land-based ecosystems for Europe and the Mediterranean. Conference: Aristotle University Environmental Council Conference, 1-11. Thessaloniki, Greece

Beresford AE, Buchanan GM, Donald PF, Butchart SHM, Fishpool LDC, Rondinini C (2011) Poor overlap between the distribution of protected areas and globally threatened birds in Africa. Anim Conserv 14:99-107. https://doi.org/10.1111/j.1469-1795.2010.00398.x

BirdLife International (2017) Ecosystem profile: Mediterranean basin biodiversity hotspot. Critical Ecosystem Partnership Fund

Bruner AG, Gullison RE, Rice RE, Da Fonseca GAB (2001) Effectiveness of parks in protecting tropical biodiversity. Science 291:125-128. https://doi.org/10.1126/science.291.5501.125

Butchart SHM, Scharlemann JPW, Evans MI, Quader S, Aricò S, Arinaitwe J, Balman M, Bennun LA, Bertzky B, Besançon C, Boucher TM, Brooks TM, Burfield IJ, Burgess ND, Chan S, Clay RP, Crosby MJ, Davidson NC, de Silva N, Devenish C, Dutson GCL, Fernández DFD, Fishpool LDC, Fitzgerald C, Foster M, Heath MF, Hockings M, Hoffmann M, Knox D, Larsen FW, Lamoreux JF, Loucks C, May I, Millett J, Molloy D, Morling P, Parr M, Ricketts TH, Seddon N, Skolnik B, Stuart SN, Upgren A, Woodley S (2012) Protecting important sites for biodiversity contributes to meeting global conservation targets. PLoS ONE 7:e32529. https://doi.org/10.1371/journal.pone.0032529

Cantú-Salazar L, Orme CDL, Rasmussen PC, Blackburn TM, Gaston KJ (2013) The performance of the global protected area system in capturing vertebrate geographic ranges. Biodivers Conserv 22:10331047. https://doi.org/10.1007/s10531-013-0467-7

Carrizo SF, Lengyel S, Kapusi F, Szabolcs M, Kasperidus HD, Scholz M, Markovic D, Freyhof J, Cid N, Cardoso AC, Darwall W (2017) Critical catchments for freshwater biodiversity conservation in Europe: identification, prioritisation and gap analysis. J Appl Ecol 54:1209-1218. https://doi. org/10.1111/1365-2664.12842

CBD (2010) Decision adopted by the conference of the parties to the convention on biological diversity at its tenth meeting. Nagoya, Japan

CBD (2020) Preparation of the post-2020 global biodiversity framework. https://www.cbd.int/doc/c/9a1b/ c778/8e3ea4d851b7770b59d5a524/wg2020-02-1-02-en.pdf

Chape S, Spalding M, Jenkins M (2008) The world's protected areas: status, values and prospects in the $21 \mathrm{st}$ century. University of California Press, San Francis 
Coad L, Watson JE, Geldmann J, Burgess ND, Leverington F, Hockings M, Knights K, Di Marco M (2019) Widespread shortfalls in protected area resourcing undermine efforts to conserve biodiversity. Front Ecol Environ 17:259-264. https://doi.org/10.1002/fee.2042

Dimitrakopoulos PG, Memtsas D, Troumbis AY (2004) Questioning the effectiveness of the Natura 2000 special areas of conservation strategy: the case of Crete. Glob Ecol Biogeogr 13:199-207. https://doi. org/10.1111/j.1466-822X.2004.00086.X

Dirzo R, Young HS, Galetti M, Ceballos G, Isaac NJB, Collen B (2014) Defaunation in the anthropocene. Science 345:40-406. https://doi.org/10.1126/science.1251817

Dudley N (ed) (2008) Guidelines for applying protected area management categories. IUCN, Gland

Euro+Med (2006) Euro+Med PlantBase: the information resource for Euro-Mediterranean plant diversity. http://ww2.bgbm.org/EuroPlusMed/

Commission E (1992) Council Directive 92/43/EEC of 21 May 1992 on the conservation of natural habitats and of wild fauna and flora. J. Eur. Union 206:7-50

Commission E (2009) Directive 2009/147/EC of the European Parliament and of the Council of 30 November 2009 on the conservation of wild birds. J. Eur. Union 20:7-25

European Commission (2020) Natura 2000. https://ec.europa.eu/environment/nature/natura2000/index _en.htm

European Environment Agency (2019) Natura 2000 Barometer. https://www.eea.europa.eu/data-andmaps/dashboards/natura-2000-barometer

European Environmental Agency (2019) EIONET: Central data repository. http://cdr.eionet.europa.eu/ gr/eea/cdda1/

Flora of Greece Web (2018) Vascular Plants of Greece: An annotated checklist. http://portal.cybertaxon omy.org/flora-greece/intro

Gaston KJ (1994) Rarity. Population and community biology series. Springer, New York

Geldmann J, Barnes M, Coad L, Craigie ID, Hockings M, Burgess ND (2013) Effectiveness of terrestrial protected areas in reducing habitat loss and population declines. Biol Conserv 161:230-238. https ://doi.org/10.1016/j.biocon.2013.02.018

Geldmann J, Coad L, Barnes MD, Craigie ID, Woodley S, Balmford A, Brooks TM, Hockings M, Knights K, Mascia MB, McRae L, Burgess ND (2018) A global analysis of management capacity and ecological outcomes in terrestrial protected areas. Conserv. Lett. 11:e12434. https://doi. org/10.1111/conl.12434

Gruber B, Evans D, Henle K, Bauch B, Schmeller DS, Dziock F, Henry PY, Lengyel S, Margules C, Dormann CF (2012) Mind the gap!": How well does Natura 2000 cover species of European interest? Nat. Conserv. 3:45-63. https://doi.org/10.3897/natureconservation.3.3732

Guilhaumon F, Albouy C, Claudet J, Velez L, Ben Rais Lasram F, Tomasini JA, Douzery EJP, Meynard CN, Mouquet N, Troussellier M, Araújo MB, Mouillot D (2015) Representing taxonomic, phylogenetic and functional diversity: new challenges for Mediterranean marine-protected areas. Divers Distrib 21:175-187. https://doi.org/10.1111/ddi.12280

IPBES (2019) Summary for policymakers of the global assessment report on biodiversity and ecosystem services of the Intergovernmental Science-Policy Platform on Biodiversity and Ecosystem Services. In: Díaz S, Settele J, Brondízio ES, Ngo HT, Guèze M, Agard J, Arneth A, Balvanera P, Brauman KA, Butchart SHM, Chan KMA, Garibaldi LA, Ichii K, Liu J, Subramanian SM, Midgley GF, Miloslavich P, Molnár Z, Obura D, Pfaff A, Polasky S, Purvis A, Razzaque J, Reyers B, Roy Chowdhury R, Shin YI, Visseren-Hamakers IJ, Willis KJ, Zayas CN (eds) IPBES secretariat, Bonn.

IUCN (2016) A global standard for the identification of key biodiversity areas. Version 1. IUCN, Gland

IUCN (2018) Mapping standards and data quality for the IUCN red list categories and criteria. IUCN, Gland

IUCN (2019) The IUCN red list of threatened species. IUCN, Version 2019-2

Wcpa IUCN (2019) Guidelines for recognizing and reporting other effective area-based conservation measures. IUCN, Gland

Joint Ministerial Decision 50743/2017 (2017) Revision of the National Ecological Network Natura 2000.

Joppa L, Baillie J, Robinson JG (2016) Protected areas: are they safeguarding biodiversity? WileyBlackwell, London

Joppa LN, O’Connor B, Visconti P, Smith C, Geldmann J, Hoffmann M, Watson JEM, Butchart SHM, Virah-Sawmy M, Halpern BS, Ahmed SE, Balmford A, Sutherland WJ, Harfoot M, Hilton-Taylor C, Foden W, Di Minin E, Pagad S, Genovesi P, Hutton J, Burgess ND (2016) Filling in biodiversity threat gaps: only $5 \%$ of global threat data sets meet a "gold standard." Science 352:416-418. https ://doi.org/10.1126/science.aaf3565

Joppa LN, Pfaff A (2011) Global protected area impacts. Proc R Soc B 278:1633-1638. https://doi. org/10.1098/rspb.2010.1713 
Klein CJ, Brown CJ, Halpern BS, Segan DB, McGowan J, Beger M, Watson JEM (2015) Shortfalls in the global protected area network at representing marine biodiversity. Sci Rep 5:17539. https://doi. org/10.1038/srep17539

Legakis A, Constantinidis T, Petrakis PV (2018) Biodiversity in Greece. In: Pullaiah T (ed) Global biodiversity. Apple Academic Press Inc., London, pp 71-124

Legakis A, Maragkou P (2009) The red book of threatened species. Hellenic Zoological Society, Athens

Leverington F, Costa KL, Pavese H, Lisle A, Hockings M (2010) A global analysis of protected area management effectiveness. Environ Manage 46:685-698. https://doi.org/10.1007/s00267-010-9564-5

Lewis SL, Maslin MA (2015) Defining the anthropocene. Nature 519:171-180. https://doi.org/10.1038/ nature 14258

Maiorano L, Amori G, Montemaggiori A, Rondinini C, Santini L, Saura S, Boitani L (2015) On how much biodiversity is covered in Europe by national protected areas and by the Natura 2000 network: Insights from terrestrial vertebrates. Conserv Biol 29:986-995. https://doi.org/10.1111/cobi.12535

Maxwell SL, Fuller RA, Brooks TM, Watson JEM (2016) Biodiversity: the ravages of guns, nets and bulldozers. Nature 536:143-146. https://doi.org/10.1038/536143a

Médail F, Quézel P (1999) Biodiversity hotspots in the Mediterranean Basin: setting global conservation priorities. Conserv Biol 13:1510-1513. https://doi.org/10.1046/j.1523-1739.1999.98467.X

Myers N, Mittermeier RA, Mittermeier CG, da Fonseca GAB, Kent J (2000) Biodiversity hotspots for conservation priorities. Nature 403:853-858. https://doi.org/10.1038/35002501

Phitos D, Strid A, Snogerup S, Greuter W (1995) The red data book of rare and threatened plants of Greece. WWF Hellas, Athens

Rodrigues ASL, Akçakaya HR, Andelman SJ, Bakarr MI, Boitani L, Brooks TM, Chanson JS, Fishpool LDC, Da Fonseca GAB, Gaston KJ, Hoffmann M, Marquet PA, Pilgrim JD, Pressey RL, Schipper J, Sechrest W, Stuart SN, Underhill LG, Waller RW, Watts MEJ, Yan X (2004) Global gap analysis: priority regions for expanding the global protected-area network. Bioscience 54:1092-1100. https://doi. org/10.1641/0006-3568(2004)054[1092:GGAPRF]2.0.CO;2

Rodrigues ASL, Andelman SJ, Bakarr MI, Boitani L, Brooks TM, Cowling RM, Fishpool LDC, da Fonseca GAB, Gaston KJ, Hoffmann M, Long JS, Marquet PA, Pilgrim JD, Pressey RL, Schipper J, Sechrest W, Stuart SN, Underhill LG, Waller RW, Watts MEJ, Yan X (2004) Effectiveness of the global protected area network in representing species diversity. Nature 428:640-643. https://doi.org/10.1038/ nature 02422

Rosso A, Aragón P, Acevedo F, Doadrio I, García-Barros E, Lobo JM, Munguira ML, Monserrat VJ, Palomo J, Pleguezuelos JM, Romo H, Triviño V, Sánchez-Fernández D (2018) Effectiveness of the Natura 2000 network in protecting Iberian endemic fauna. Anim Conserv 21:262-271. https://doi. org/10.1111/acv.12387

Sfenthourakis S, Pafilis P, Parmakelis A, Poulakaelis P, Triantis K (2018) Biogeography and biodiversity of the Aegean: in honour of Prof. Broken Hill Publishers Ltd, Nicosia, Moysis Mylonas

Shanee S, Shanee N, Monteferri B, Allgas N, Alarcon Pardo A, Horwich RH (2017) Protected area coverage of threatened vertebrates and ecoregions in Peru: comparison of communal, private and state reserves. J Environ Manage 202:12-20. https://doi.org/10.1016/j.jenvman.2017.07.023

Trigas P, Tsiftsis S, Tsiripidis I, Iatrou G (2012) Distribution patterns and conservation perspectives of the endemic flora of peloponnese (Greece). Folia Geobotanica 47:421-439. https://doi.org/10.1007/s1222 4-012-9130-4

Trochet A, Schmeller D (2013) Effectiveness of the Natura 2000 network to cover threatened species. Nat. Conserv. 4:35-53. https://doi.org/10.3897/natureconservation.4.3626

UNEP-WCMC, IUCN (2020) Protected Planet: Protected Area Profile for Greece from the World Database of Protected Areas; The World Database on Protected Areas (WDPA)/The Global Database on Protected Areas Management Effectiveness (GD-PAME) On-line, February 2020, Cambridge, UK: UNEP-WCMC and IUCN. www.protectedplanet.net

United Nations (2015) Transforming our world: the 2030 Agenda for Sustainable Development. General Assembly 70 session

Venter O, Fuller RA, Segan DB, Carwardine J, Brooks T, Butchart SHM, Di Marco M, Iwamura T, Joseph L, O'Grady D, Possingham HP, Rondinini C, Smith RJ, Venter M, Watson JEM (2014) Targeting global protected area expansion for imperiled biodiversity. PLoS Biol 12:e1001891. https://doi. org/10.1371/journal.pbio.1001891

Watson JEM, Evans MC, Carwardine J, Fuller RA, Joseph LN, Segan DB, Taylor MFJ, Fensham RJ, Possingham HP (2010) The capacity of Australia's protected-area system to represent threatened species. Conserv Biol 25(2):324-332. https://doi.org/10.1111/j.1523-1739.2010.01587.x

Watson JEM, Dudley N, Segan DB, Hockings M (2014) The performance and potential of protected areas. Nature 515:67-73. https://doi.org/10.1038/nature13947 
Publisher's Note Springer Nature remains neutral with regard to jurisdictional claims in published maps and institutional affiliations.

\section{Authors and Affiliations}

Konstantina Spiliopoulou ${ }^{1,2}$ (D) Panayiotis G. Dimitrakopoulos ${ }^{3}$ (D)

Thomas M. Brooks ${ }^{4}$ D $\cdot$ Gabriela Kelaidi $^{2} \cdot$ Kaloust Paragamian $^{5}$ (D) Vassiliki Kati $^{6}$ (D) . Anthi Oikonomou ${ }^{1}$ (D) Dimitris Vavylis ${ }^{2} \cdot$ Panayiotis Trigas $^{7}$ (D) Petros Lymberakis ${ }^{8}$ (D) William Darwall $^{9}$ D $\cdot$ Maria Th. Stoumboudi ${ }^{1} \cdot$ Kostas A. Triantis $^{2}$ (D)

1 Institute of Marine Biological Resources and Inland Waters, Hellenic Centre for Marine Research, 19013 Anavissos, Greece

2 Department of Ecology and Taxonomy, Faculty of Biology, National and Kapodistrian University of Athens, 15784 Athens, Greece

3 Biodiversity Conservation Laboratory, Department of Environment, University of the Aegean, 81100 Mytilene, Greece

4 Science and Knowledge Unit, International Union for Conservation of Nature (IUCN), 1196 Gland, Switzerland

5 Hellenic Institute of Speleological Research, 71409 Irakleio, Crete, Greece

6 Department of Biological Applications and Technology, University of Ioannina, 45110 Ioannina, Greece

7 Faculty of Crop Science, Agricultural University of Athens, 11855 Athens, Greece

8 Natural History Museum of Crete, University of Crete, 71409 Irakleio, Greece

9 Freshwater Biodiversity Unit, IUCN Global Species Programme, The David Attenborough Building, Cambridge CB2 3QZ, UK 